Andrade Rosário Nacha Samadi, de Souza Perciliany Martins, Assunção Poliana Elisa, Pereira de Oliveira Fernando Luiz, Bearzoti Eduardo, de Castro Pinto Kelerson Mauro, Souza Gabriela Guerra Leal. Resting heart rate variability in professors: Impact of psychological stress, obesity and blood pressure. Journal of Education, Health and Sport. 2021;11(5):11-25. eISSN 23918306. DOI http://dx.doi.org/10.12775/JEHS.2021.11.05.001

https://apcz.umk.pl/czasopisma/index.php/JEHS/article/view/JEHS.2021.11.05.001

https://zenodo.org/record/4733067

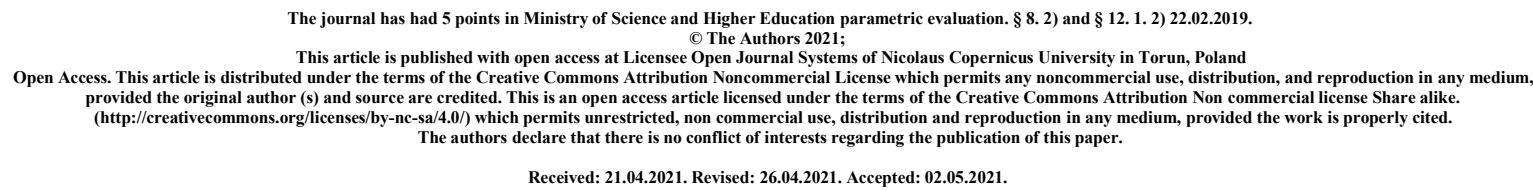

\title{
Resting heart rate variability in professors: Impact of psychological stress, obesity and blood pressure
}

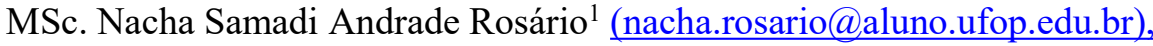
MSc. Perciliany Martins de Souza ${ }^{1}$ (perciliany.souza@aluno.ufop.edu.br), Poliana Elisa Assunção ${ }^{1}$ (popoelisa@gmail.com), $\mathrm{PhD}$. Fernando Luiz Pereira de Oliveira² (fernandoluiz@ufop.edu.br), PhD. Eduardo Bearzoti² (eduardo.bearzoti@ufop.edu.br), PhD. Kelerson Mauro de Castro Pinto3 (kelerson@ufop.edu.br), and PhD. Gabriela Guerra Leal Souza1 (gabriela.souza@ufop.edu.br).

1. Laboratory of Psychophysiology, Department of Biological Sciences, Federal University of Ouro Preto, Ouro Preto, Brazil

2. Department of Statistics, Federal University of Ouro Preto, Ouro Preto, Brazil

3. School of Physical Education, Federal University of Ouro Preto, Ouro Preto, Brazil

Corresponding author: Gabriela Guerra Leal Souza; Federal University of Ouro Preto, Department of Biological Sciences, Campus Morro do Cruzeiro, Laboratory of Psychophysiology - Ouro Preto, Minas Gerais - Brasil. CEP 35400-000; e-mail: gabriela.souza@ufop.edu.br; +55 (31) 3559-1991 / (31)9 8864-2549Email

\begin{abstract}
Objective: University professors are prone to show physical and psychological diseases related to excessive workload. Such overwork can affect the functioning of the autonomic nervous system, leading to a decrease in heart rate variability (HRV). HRV reflects the continuous fluctuation of the R-R intervals due to sympathetic and parasympathetic actions in the heart and is associated with good physical and psychological health. We aimed to evaluate whether psychological stress and anthropometric and clinical variables influence HRV at rest in professors. Methods: University professors of both sexes $(\mathrm{N}=65 ; 41 \mathrm{men})$ participated. We collected Anthropometry and Clinical variables, Psychological stress, and HRV parasympathetic parameters (square root mean squares of the differences between RR intervals: RMSSD, number of successive differences between RR intervals, which are > 50 ms: NN50 and high frequency - HF). Results: Four principal components (PCs) represented 68.29\% of the data total variation. Principal component 1 (PC1) was called the good cardiac regulation component. PC2 was called the component of reduced stress symptoms. PC3 was named favorable working conditions component. PC4 was denominated component of labor and physiological deregulation. Each HRV parameter was associated with each PC through the use of regression models. The RMSSD was positively associated with PC2. The NN50 was positively associated with PC2 and PC3. HF was positively associated with PC3 and PC4. Conclusions: HRV parasympathetic parameters, which represent good physical and mental health, are positively associated with the components of reduced stress symptoms, favorable working conditions, and labor and physiological deregulation.
\end{abstract}

Key words: heart rate variability; stress; blood pressure; obesity; anthropometry; professors. 


\begin{abstract}
Abstrata
Objetivo: Professores universitários são propensos a apresentar doenças físicas e psicológicas relacionadas à carga horária excessiva. Esse excesso de trabalho pode afetar o funcionamento do sistema nervoso autônomo, levando a uma diminuição da variabilidade da frequência cardíaca (VFC). A VFC reflete a flutuação contínua dos intervalos RR devido às ações simpáticas e parassimpáticas no coração e está associada a uma boa saúde física e psicológica. Objetivamos avaliar se o estresse psicológico e as variáveis antropométricas e clínicas influenciam a VFC em repouso em professores. Métodos:Participaram professores universitários de ambos os sexos $(\mathrm{N}=65$; 41 homens). Coletamos variáveis antropométricas e clínicas, estresse psicológico e parâmetros parassimpáticos da VFC (raiz quadrada da média dos quadrados das diferenças entre os intervalos RR: RMSSD, número de diferenças sucessivas entre os intervalos RR, que são> 50 ms: NN50 e alta frequência - HF). Resultados: Quatro componentes principais (PCs) representaram 68,29\% da variação total dos dados. O componente principal 1 (PC1) foi denominado componente de boa regulação cardíaca. PC2 foi chamado de componente de redução dos sintomas de estresse. O PC3 foi denominado componente de condições favoráveis de trabalho. PC4 foi denominado componente do parto e desregulamentação fisiológica. Cada parâmetro de VFC foi associado a cada PC por meio do uso de modelos de regressão. O RMSSD foi positivamente associado ao PC2. O NN50 foi associado positivamente com PC2 e PC3. HF associou-se positivamente com PC3 e PC4. Conclusões: Os parâmetros parassimpáticos da VFC, que representam boa saúde física e mental, estão positivamente associados aos componentes de redução dos sintomas de estresse, condições favoráveis de trabalho e desregulamentação fisiológica e laboral.
\end{abstract}

Palavras-chave: variabilidade da freqüência cardíaca; estresse; pressão sanguínea; obesidade; antropometria; professores.

\title{
Introduction
}

University professors are prone to show physical and psychological diseases related to excessive workload (Santos et al.,2018; Hajare, 2018). Huang, Webb, Zourdos, \& Acevedo (2013) have shown that the psychological and physical symptoms of stress contribute partially to the risk of cardiovascular diseases and to the increase in mortality experienced in some professions. One of the professions characterized by a high prevalence of stress symptoms is teaching (Silveira, Enumo, Paula, \& Batista, 2014). Mental stress experienced by professors can lead to psychological disorders, such as anger, anxiety, and frustration, and these disorders are associated with an increased sympathetic tone and increased blood pressure (Chatkoff, Maier, \& Klein, 2010; Schutz, 2014; Frenzel et al., 2016). Different sources of stress in university teaching work have been pointed out. Among these sources, there are overwork and lack of time resulting from teaching, research, extension and administrative activities (Fidalgo, 2010; Reis \& Cecílio, 2014; Sanchez et al., 2019). Thus, a routine of multiple tasks, different working days, and irregular schedules, typical of this profession, contribute to generate high levels of stress and, therefore, can influence their diet, leading to poor eating habits, obesity (Braga \& Paternez, 2011; Oliveira et al., 2011), and hypertension (Moreira, et al., 2011; Santos, 2018)

These physical and psychological changes can affect the functioning of the autonomic nervous system, leading to a decrease in heart rate variability (HRV) along with other pathologies (Thayer, Yamamoto, \& Brosschot, 2010; Rossi et al., 2015; Pulopulos, Vanderhasselt, \& De Raedt, 2018). HRV is a noninvasive measurement that reflects the continuous oscillation of the RR intervals due to sympathetic and parasympathetic actions in the sinoatrial node (Task Force, 1996; Laborde, Mosley, \& Thayer, 2017). Due to practicality, low cost and efficiency, a significant number of studies have used HRV analysis as a tool for investigating several topics related to health and emotions (Balzarotti et al., 2017). A reduced HRV is commonly used as an indicator of irregular and insufficient adaptation of the ANS and it is associated with physical and mental diseases (Beauchaine \& Thayer, 2015; Benichou et al., 2018). There are two theories that explain the HRV from a functional perspective. The polyvagal theory proposed that the HRV increases in a secure context (by activation of myelinated vagus) to induce social behavior, and in an aversive context, the HRV is reduced by the activation of the sympathetic adrenal system and by deactivation of the unmyelinated vagus (Porges, 2007). The Neurovisceral Integration Model proposed that higher HRV is associated with better perform on executive-function tasks in a wide range of situations mediated by activation of the prefrontal Cortex (Thayer et al., 2009).

Factors could influence HRV regulation. It was demonstrated that clinical variables such as high blood pressure and high Heart Rate (HR) in rest are associated with low HRV (Monteze 
et al., 2015; Yue et al., 2014). Another influencing factor is obesity, a serious public health problem (Martins, 2018) that is linked to the deregulation of the autonomic function, contributing to a decrease in HRV, and, consequently, an increase in mortality and morbidity (Monteze et al., 2015; Yadav et al., 2017). Finally, psychological stress is also associated with low HRV (Pulopulos, Vanderhasselt, \& De Raedt, 2018; Kim, Cheon, Bai, Lee, \& Koo, 2018). It is important to highlight that the factors mentioned above, that is, psychological stress, obesity, clinical variables, and HRV measurements have sexual differences, as we can see in these studies: women present more psychosocial risk factors, work stress, social stress, and poorer mental health than men (Verma, Balhara \& Gupta, 2011; Mayor, 2015). As stated by Kanter \& Caballero (2012), the prevalence of overweight and obesity is higher among women, and in developing countries, sex differences are greater. Regarding sexual differences in hypertension, levels are higher in men than in women until after menopause (Reckelhoff, 2018). Finally, regarding differences in HRV at rest, it was shown that women typically exhibit higher HRV at rest than men (Koenig \& Thayer, 2016).

To the best of our knowledge, there are no studies in the literature that investigated the relationship between psychological stress, obesity, and clinical and HRV variables among individuals in a sample of university professors, using the principal component analysis, and whether each component influences HRV at rest. We believe that this sample is a good model to study all these variables together because it suffers a negative influence on all these variables in its health, as shown in the studies above. Therefore, the main aim of the present exploratory study was to investigate whether psychological stress and anthropometric and clinical variables influence the HRV at rest of university professors. Our hypotheses were that (i) independent variables (psychological stress, and clinical and anthropometric variables) would be associated with each other (as indicated by the Principal Component Analysis [PCA]) and would generate components that could be explained biologically; (ii) the principal components (PCs) related to greater psychological stress and worse anthropometric and clinical variables would have a negative association with the parasympathetic components of the HRV at rest; and (iii) there would be gender differences in the anthropometric, clinical, psychological stress, and resting HRV components. We expected higher stress, obesity and HRV parameters in women and higher blood pressure in men.

\section{Study design and sample}

\section{Methods}

This is an exploratory study of the cross-sectional type, carried out in a population of male and female university professors from the Federal University of Ouro Preto, generated by convenience sampling. The professors $(\mathrm{N}=264)$ were invited by letter. After the letter was delivered, the researchers contacted the professors in person to determine whether they met the inclusion criteria and were interested in voluntarily participating in the experiment. Inclusion criteria consisted of individuals between 25 and 65 years of age, non-smokers, not taking medication that acts on the nervous system, and having no diagnosis of psychiatric, psychological, or cardiac diseases. All inclusion criteria were self-declared. A sample of 84 professors volunteered to participate in the experiment; however, 19 were excluded because they did not meet the parameters. The recommendations for taking part in the experiment were as follows: no intense physical exercise 48 hours before the evaluation; no ingestion of alcoholic beverages or use of licit or illicit drugs 24 hours before the evaluation; and no consumption of any beverage or food that contains caffeine 12 hours before the evaluation. The protocol was approved by the Local Institutional Review Board (CAAE: 32882614.3.0000.5150), and all professors signed the free and informed consent form on the day of the experiment. 


\section{Data collection}

\section{Heart rate variability}

HRV was collected using a Polar S810 heart rate monitor for five minutes while the volunteer was sitting and relaxed. This length is in agreement with extensive literature (Task Force, 1996; Ernst, 2017; Laborde, Mosley, \& Thayer, 2017). The time units were set at $1 \mathrm{ms,}$, and the RR interval samples were collected at a sampling frequency of $1000 \mathrm{~Hz}$. We followed the recommendations of Laborde, Mosley, \& Thayer, (2017) for data collection and reporting. All evaluations were carried out from 8 am to $4 \mathrm{pm}$, because during this period there are no major HRV fluctuations (Hayano \& Yasuma, 2003; and Sammito, Sammito \& Böckelmann, 2016).

HRV was analyzed in the time and frequency domains. The components of the time domain used were the Root Mean Square of Successive Differences of the RR intervals (RMSSD), and the number of interval differences of successive RR intervals was greater than $50 \mathrm{~ms}$ (NN50), and the frequency domain component included high frequency (HF: 0.15-0.4 Hz). As these indexes are well established in the literature as representatives of parasympathetic activity (Task Force, 1996; Kop et al., 2010; Xhyheri, Manfrini, Mazzolini, Pizzi, \& Bugiardini, 2012), we decided to use them.

The data obtained by the HR monitor were transferred to a computer using the Polar Pro Trainer 5 software, through an interface with an infrared device. Then, this database was exported as text, and the RR interval signals were processed to calculate HRV using the Kubios HRV Analysis software (MATLAB, version 2 beta, Kuopio, Finland).

Psychological Stress

- The Lipp Stress Symptoms Inventory for Adults (LSSI; Lipp, 2000) is a questionnaire that provides a measure of stress symptomatology that divides stress into three phases according to the physical and psychological symptoms experienced in a given time period: alarm phase (previous 24 hours), resistance phase (previous week), and exhaustion phase (previous month). The Cronbach's alpha of this scale is 0.91.

- $\quad$ Work stress questionnaire (Theorell \& Karasek, 1996), translated into and validated for Portuguese by Alves, Chor, Faerstein, Lopes and Werneck (2004), is a questionnaire that measures the following dimensions: 1) work demand, which refers to psychological pressures, either quantitative (e.g. work time and speed) or qualitative (e.g. conflicts between contradictory demands); 2) work control, which is the possibility of workers to use their intellectual skills to perform their work, and to have sufficient authority to make decisions on how to perform it; and 3) work social support, which is defined as the levels of social interaction that exist at work, both with co-workers and supervisors. The Cronbach's alpha of the portuguese version of the work stress questionnaire was 0.72 for demand, 0.63 for control, and 0.86 for social support.

- Vital Events Scale (Savoia, 1999) is a 26-item scale that assesses which vital events people have experienced in the previous year. Those events may be categorized according to stressor into the following categories: work, loss of social support, family, environment changes, personal difficulties, and finances. This scale is based on the proposition that the effort made by individuals to readjust to society after significant changes in their lives causes deterioration that may lead to serious illness.

\section{Anthropometry}

To obtain body mass (using a balance of the brand EKS Super 9805), height (using a stadiometer of the brand WISO), and circumference measurements (using an anthropometric tape measure), the volunteer remained in an anatomical position and wore the minimum clothing possible. Body mass $(\mathrm{kg})$ and height $(\mathrm{m})$ data were used to calculate body mass index (BMI) by dividing the body mass by height squared (WHO, 2000). Waist circumference (WC) was measured at the midpoint between the last rib and the iliac crest (IDF, 2006), and hip circumference (HC) was measured at the level of the widest portion of the buttocks (WHO, 
2000). WC and HC values were used to calculate waist/hip ratio (WHR). Fat percentage was measured according to the protocol of Guedes \& Guedes (1998), and then, a formula was applied to calculate the body fat percentage (BF\%) (Durnin \& Womersley, 1974).

\section{Clinical Measurements}

Blood pressure (BP) and resting heart rate (HRrest) were measured using an Omron Intellisense M3 automatic digital sphygmomanometer. BP and HRrest were measured three times, with a minimum interval of one minute between measurements. Subjects were instructed not to smoke or drink coffee within the 30 minutes prior to the measurement procedure and not to speak during the measurements (SBC, 2010).

\section{Procedures}

The volunteers were invited by letter and were later scheduled to undergo experiments in the laboratory. All evaluations were carried out from 8 am to $4 \mathrm{pm}$. Upon arriving at the Psychophysiology laboratory, on the day scheduled, professors received the Informed Consent Term, and then read and signed it. Soon after, the anthropometric measures were collected: body mass, height, hip and waist circumference, and fat percentage. At that time, the cardiac pacemaker and thoracic band were placed, and then the following questionnaires were answered during about 20 minutes: Lipp Stress Symptom Inventory for Adults, Work Stress, Perceived Stress, and Vital Events Scale. Afterwards, the volunteers underwent a one-minute complete rest and, subsequently, HRV was recorded for five minutes in the sitting position. Finally, three clinical measurements were made to record blood pressure and resting heart rate with an interval of one minute between them. During all physiological recordings participants were instructed to relax and not to speak or make any movements. The total duration of the experiment was approximately 40 minutes.

\section{Statistics}

The hypothesis of normal distribution was verified for all variables using the Shapiro-Wilk test. Variables regarded as normal had their values summarized using the mean and the standard deviation, while non-normal variables were described using the $1^{\text {st }}, 2^{\text {nd }}$, and $3^{\text {rd }}$ quartiles, calculated with Statistica software version 7.0. To determine whether there was sex difference in the anthropometric, clinical, psychological stress, and HRV components, Student's t-test $(p<0.05)$ was used for normal variables, while the Mann-Whitney U nonparametric test $(\mathrm{p}<0.05)$ was used for non-normal variables, using Statistica software version 7.0 .

It was used the Principal Component Analysis (PCA), which was performed using R language (R Core Team, 2017), version 3.3.1 to summarize the 13 collected variables: BMI, WC, WHR, SBP, diastolic blood pressure (DBP), HRrest, demand, control, social support, vital events, stress symptoms in 24 hours, stress symptoms in one week, and stress symptoms in one month. Therefore, in general, the PCA is a multivariate statistical method, whose main objective is to detect the common variation between the original variables and then to condense the data by obtaining other variables, called principal components (PCs). The PCs obtained are linear combinations of the original variables and each $\mathrm{PC}$ is, by definition, uncorrelated with the others. The first PC (PC1) obtained accumulates most of the total variation among the studied variables, while the next components (PC2, PC3, etc.) represent, respectively, lower variation. Thus, each new PC progressively includes smaller variation fractions, which are expressed by their "own values." Each PC has its own value, which is obtained by summing the squares of the correlations between the original independent variables and the respective PC, and this sum represents the variation fraction assigned to each PC. Only PCs with corresponding eigenvalues greater than one were retained.

In this study, a varimax rotation was used, and a given variable was only considered relevant in a PC if its corresponding loading was $\geq 0.30$. In addition, the Kaiser-Meyer-Olkin test was used to verify the adequacy of the sample. After obtaining the PCs, they were used as 
predictive variables in regression models $(\mathrm{p}<0.05)$ with each of the HRV components as a response variable. These models were adjusted using backward elimination of predictive variables (Draper \& Smith, 2014), with a cut-off p-value of 0.1. This method starts with a model containing all variables, some of which may be removed in subsequent steps. The initial models also contained a dummy variable to account for sex (assuming value 1 for males and 0 for females), as well as the products of this dummy variable and PCs. For illustration purposes, consider a class with three variables, $\mathrm{X} 1, \mathrm{X} 2$, and $\mathrm{X} 3$, and the dummy variable expressed as Z. Thus, for a response variable $\mathrm{Y}$, the initial model (disregarding the residual) would be:

$Y=\beta_{0}+\beta_{1} Z+\beta_{2} X_{1}+\beta_{3} X_{2}+\beta_{4} X_{3}+\beta_{5} X_{1} * Z+\beta_{6} X_{2} * Z+\beta_{7} X_{3} * Z$

Suppose that after the application of the backward method, the following final model has been obtained as follows:

$Y=\beta_{0}+\beta_{1} Z+\beta_{4} X_{3}+\beta_{5} X_{1} * Z+\beta_{7} X_{3} * Z$

In this way, for women we have:

$\mathrm{Y}=\beta_{0}+\beta_{4} \mathrm{X}_{3}$

For men, we have:

$Y=\left(\beta_{0}+\beta_{1}\right)+\beta_{5} X_{1}+\left(\beta_{4}+\beta_{7}\right) X_{3}$

In this type of situation, it would be concluded that $X_{1}$ was significant for men and $X_{3}$ was significant for women. To determine whether $\mathrm{X}_{3}$ was significant for males, the $t$ hypothesis test $\left(\beta_{4}+\beta_{7}\right)=0$ should be conducted. Sex, PC, and interaction between sex and PC were used as independent variables; each of the HRV components was used as a dependent variable and a different regression was performed for each component.

\section{Results}

The final sample consisted of 65 professors, with 41 (63.1\%) males and 24 (36.9\%) females and a median age of 42 years (36-50). The median working time at the university was five (38) years.

The anthropometric variables body mass, height, BMI, WC, and WHR were higher in men than in women, while BF\% was higher in women. For the clinical variables, significant differences were found between the sexes in SBP and DBP, with higher values for men. For the stress variables, sex difference was found in total stress symptoms for one week, with higher values for females. No significant differences were found between sexes in the HRV variables. See Table 1 for details. 
Table 1: Characteristics of the studied sample and difference between the sexes.

\begin{tabular}{|c|c|c|c|c|c|}
\hline Variable & \multicolumn{2}{|c|}{$\begin{array}{c}\text { Male }(41) \\
\text { Mean } \pm \text { SD/Median } \\
(\mathrm{p} 25 / \mathrm{p} 75)\end{array}$} & \multicolumn{2}{|c|}{$\begin{array}{c}\text { Female }(24) \\
\text { Mean } \pm \text { SD/Median } \\
(\mathrm{p} 25 / \mathrm{p} 75)\end{array}$} & \multirow[t]{2}{*}{$\mathrm{P}$} \\
\hline \multicolumn{5}{|l|}{ Anthropometric } & \\
\hline Body mass (kg) & 79.8 & \pm 13.0 & 61.3 & \pm 8.6 & $<0.001 *$ \\
\hline Height (m) & 1.75 & \pm 0.08 & 1.61 & \pm 0.05 & $<0.001 *$ \\
\hline BMI $\left(\mathrm{kg} / \mathrm{m}^{2}\right)$ & 25.9 & \pm 3.7 & 23.8 & \pm 2.9 & $0.02 *$ \\
\hline Waist circumference $(\mathrm{cm})$ & 88.8 & \pm 9.7 & 73.4 & \pm 6.4 & $<0.001 *$ \\
\hline Hip circumference $(\mathrm{cm})$ & 97.0 & $(94.0 / 103.0)$ & 98.3 & $(96.0 / 103.5)$ & 0.78 \\
\hline Waist-hip ratio & 0.89 & \pm 0.06 & 0.74 & \pm 0.05 & $<0.001 *$ \\
\hline Body fat (\%) & 20.5 & \pm 5.3 & 27.66 & \pm 3.09 & $<0.001 *$ \\
\hline \multicolumn{6}{|l|}{ Clinical } \\
\hline Mean SBP (mm Hg) & 124 & \pm 10 & 108.96 & \pm 9.48 & $<0.001 *$ \\
\hline Mean DBP (mm Hg) & 78 & \pm 8 & 68.33 & \pm 7.79 & $<0.001 *$ \\
\hline HRrest (bpm) & 71 & \pm 11 & 75.49 & \pm 9.42 & 0.07 \\
\hline \multicolumn{6}{|l|}{ HRV } \\
\hline RMSSD (ms) & 29.9 & $(20.4 / 39.7)$ & 31.2 & $(22.7 / 40.4)$ & 0.94 \\
\hline NN50 (ms) & 30.0 & $(9.0 / 63.0)$ & 33.5 & $(12.5 / 62.5)$ & 0.69 \\
\hline $\mathrm{HF}\left(\mathrm{ms}^{2}\right)$ & 473.0 & $(277.3 / 2825.1)$ & 488.4 & $(275.6 / 912.4)$ & 0.72 \\
\hline \multicolumn{6}{|l|}{ Stress } \\
\hline \multicolumn{6}{|l|}{ Stress at work } \\
\hline Demand & 15 & $(13-16)$ & 16 & $(14-18)$ & 0.10 \\
\hline Control & 20 & $(19 / 21)$ & 20 & $(19 / 21)$ & 0.58 \\
\hline Social support & 18 & $(16 / 20)$ & 18 & $(15 / 21)$ & 0.72 \\
\hline Vital events & 3 & $(2 / 4)$ & 3 & $(2 / 6)$ & 0.38 \\
\hline \multicolumn{6}{|l|}{ Stress symptoms of Lipp } \\
\hline Total $24 \mathrm{~h}$ & 1 & $(0 / 2)$ & 2 & $(1 / 3.5)$ & 0.17 \\
\hline Total 1 week & 2 & $(0 / 4)$ & 3.5 & $(1 / 5.5)$ & $0.02 *$ \\
\hline Total 1 month & 2 & $(1 / 5)$ & 3.5 & $(2 / 5.5)$ & 0.06 \\
\hline $\begin{array}{l}\text { BMI - Body mass index; m } \\
\text { pressure; DBP - Diastolic b } \\
\text { interval differences; NN50 } \\
\text { previous interval; HF - Hig } \\
\text { Mann-Whitney U test. }\end{array}$ & $\begin{array}{l}\text { illim } \\
\text { ure; } \\
\text { ce nu; }\end{array}$ & $\begin{array}{l}\text { mercury; bpm } \\
\text { Heart rate; RM } \\
\text { of RR intervals } \\
5 \text { was considere }\end{array}$ & $\begin{array}{l}\text { eats } p \\
- \text { Roc } \\
\text { diffe } \\
\text { tistica }\end{array}$ & $\begin{array}{l}\text { ute; SBP }-\mathrm{S} \\
\text { n square of } \mathrm{s} \\
\text { ore than } 50 \\
\text { nificant. Stuc }\end{array}$ & $\begin{array}{l}\text { lic blood } \\
\text { essive RR } \\
\text { from the } \\
\text { s T-Test/ }\end{array}$ \\
\hline
\end{tabular}

In the PCA, the first 4 PCs were retained for having eigenvalues $\geq 1.0$ (Kaiser criterion) (Mardia, Kent, \& Bibby, 1979). Together, these four components accounted for $68.29 \%$ of the total data change. Table 2 shows the loads related to the variables in each component.

For PC1, corresponding to $29,14 \%$ of the total variation, five variables presented higher loads than the pre-defined cut-off point (BMI, WC, WHR, SBP, and DBP) and were termed a "good cardiac regulation" component, since the load signals were negative for all five, interpreting low values for these variables.

PC2 encompassed vital events, 24-hour stress symptoms, one-week stress symptoms, and onemonth stress symptoms (the signs were negative for all (Table 2), thus interpreting low values for stress), and was responsible for $21.92 \%$ of the total variation, termed the "reduced stress symptoms" component.

PC3, with $9.27 \%$ of the total variance, included demand at work (negative load signal), and social support at work (positive load signal), and was termed component of "favorable 
working conditions"; the load signals suggested low demand and high social support and this situation was considered favorable.

PC4 was composed of HRrest (positive load signal) and the control of labor activities (negative load signal) was responsible for $7.97 \%$ of the total variation, and was termed the component of "labor and physiological deregulation" because the signs of the loads showed high resting HRV and low labor control.

The adequacy of the sample was satisfactory for PCA because the Kaiser-Meyer-Olkin test showed an adequacy value of 0.73 and we also used Bartlett's Sphericity Test to check whether there was sufficient correlation for the use of PCA $(p<0.01)$.

Table 2: Variable loading* matrix and explained variance related to each $\mathrm{PC}$ after varimax rotation.

\begin{tabular}{|c|c|c|c|c|}
\hline Variable & PC1 & PC2 & PC3 & PC4 \\
\hline BMI $\left(\mathrm{kg} / \mathrm{m}^{2}\right)$ & -0.337 & -0.249 & -0.078 & -0.175 \\
\hline $\mathrm{WC}(\mathrm{cm})$ & -0.404 & -0.274 & 0.032 & -0.200 \\
\hline WHR & -0.403 & -0.161 & 0.081 & -0.100 \\
\hline Mean SBP (mmHg) & -0.379 & -0.220 & 0.042 & 0.280 \\
\hline Mean DBP (mmHg) & -0.334 & -0.294 & -0.152 & 0.209 \\
\hline Resting HR (bpm) & 0.046 & -0.105 & -0.385 & 0.428 \\
\hline Control & -0.169 & 0.150 & -0.122 & -0.639 \\
\hline Demand & 0.179 & -0.309 & -0.421 & -0.278 \\
\hline Social support & -0.112 & 0.069 & 0.718 & -0.010 \\
\hline Vital events & 0.113 & -0.370 & 0.188 & 0.240 \\
\hline Total 24 hours & 0.242 & -0.331 & 0.053 & -0.230 \\
\hline Total 1 week & 0.292 & -0.402 & 0.183 & -0.107 \\
\hline Total 1 month & 0.272 & -0.400 & 0.184 & -0.085 \\
\hline $\begin{array}{l}\text { Proportion of the } \\
\text { explained variance }(\%)\end{array}$ & 29.14 & 21.92 & 9.27 & 7.97 \\
\hline $\begin{array}{l}\text { Cumulative explained } \\
\text { variation }(\%)\end{array}$ & 29.14 & 51.06 & 60.32 & 68.29 \\
\hline \multicolumn{5}{|c|}{$\begin{array}{l}\text { BMI - Body mass index; } \mathrm{kg} / \mathrm{m} 2 \text { - Kilograms per square meter; WC - Waist circumference; } \\
\text { WHR - Waist-hip ratio; HR - Heart rate; bpm - Beats per minute; SBP - Systolic blood } \\
\text { pressure; DBP - Diastolic blood pressure; } \mathrm{mmHg}-\text { Millimeters of mercury; *Loading denotes } \\
\text { the contribution of the variable for each PC. A higher absolute value indicates that the variable } \\
\text { has a major influence on the PCs. PC1: component of good cardiac regulation; PC2: component } \\
\text { of reduced stress symptoms; PC } 3 \text { : component of favorable working conditions; PC4: } \\
\text { component of labor and physiological deregulation. }\end{array}$} \\
\hline
\end{tabular}

To understand the results described below, it should be taken into account that, when the abbreviation PC appears alone, it indicates an effect of equal magnitude in both sexes on the associated HRV parameter. When the abbreviation $\mathrm{PC} * \mathrm{Z}$ (dummy variable, to verify the influence of sex) appears alone, it indicates a significant effect only for males. Finally, when both abbreviations $\mathrm{PC}$ and $\mathrm{PC} * \mathrm{Z}$ appear, it indicates that the effect was significant for females; in this case, in order to also verify whether the effect was significant for males, it is necessary to perform a t-test to check if the sum of these two terms is statistically different from zero; if the $\mathrm{t}$ test has a significant result, it is also significant for males; however, the magnitude of influence of both sexes is different (Table 3).

PC2 (component of reduced stress symptoms) was positively associated with the RMSSD and the NN50, only for men, that is, the greater the parasympathetic activity, the greater the reduced stress symptoms for men. PC3 (component of favorable working conditions) was positively associated with the NN50 for men, and positively associated with HF for women. 
Thus, the greater the parasympathetic activity, the greater the favorable working conditions in both sexes. Finally, there was a positive association between PC4 (component of labor and physiological deregulation) and $\mathrm{HF}$ for men and women, that is, the greater the parasympathetic activity, the greater the labor and physiological deregulation (table 3 ).

Table 3: Principal components associated with HRV parameters as selected $(p<0.1)$ by the method of backward elimination in regression models with interaction terms with a dummy variable to discriminate sexes.

\begin{tabular}{|c|c|c|c|}
\hline Component/Variable & Estimate & SE & $\mathbf{P}$ \\
\hline \multicolumn{4}{|l|}{ RMSSD $\left(\mathrm{R}^{2}=0.07\right)$} \\
\hline $\mathrm{PC} 2 * \mathrm{Z}(\mathrm{M})$ & 5.0 & 2.3 & 0.03 \\
\hline \multicolumn{4}{|l|}{ NN50 $\left(\mathrm{R}^{2}=0.13\right)$} \\
\hline$\overline{\mathrm{PC} 2 * \mathrm{Z}(\mathrm{M})}$ & 7.3 & 3.9 & 0.07 \\
\hline $\mathrm{PC} 3 * \mathrm{Z}(\mathrm{M})$ & 13.5 & 6.1 & 0.03 \\
\hline \multicolumn{4}{|l|}{ HF $\left(\mathrm{R}^{2}=0.19\right)$} \\
\hline PC3 (W) & 7964.3 & 4417.4 & 0.08 \\
\hline PC3+ PC3*Z (t-test) (M) & -329120.3 & -164354.8 & 0.05 \\
\hline $\mathrm{PC} 4(\mathrm{~W} / \mathrm{M})$ & 8706.1 & 2958.9 & $<0.001$ \\
\hline
\end{tabular}

For the t-test, significant $\mathrm{p}<0.05$ was considered.

RMSSD: time domain encompassed the root mean square of successive differences of the RR intervals; NN50: number of interval differences of successive RR intervals greater than $50 \mathrm{~ms}$; HF: high frequency; Z $=$ interactions with sex.

PC2: component of reduced symptoms of stress; PC3: component of favorable working conditions; PC4: component of labor and physiological deregulation. $\mathrm{M}=\mathrm{man} ; \mathrm{W}=$ woman.

\section{Discussion}

This study found an association between anthropometric, clinical, and psychological stress variables with the parasympathetic HRV parameters in university professors, as well as the influence of sex on these associations. Four PCs were obtained, good cardiac condition, reduced symptoms of stress, favorable working condition, and labor and physiological deregulation, representing $68.29 \%$ of the total data variation.

PC1 (good cardiac health) included the anthropometric measures, BMI, WC, WHR, and two clinical variables, SBP and DBP. Anthropometric variables are used as indicators of obesity and are known to be highly intercorrelated and indicate that they may reflect the individual's central obesity (Hu et al., 2017; Fang et al., 2018). And this, in turn, is associated with dysfunction of autonomic cardiac modulation, causing an imbalance in ANS, in which there is an increase in sympathetic activity and/or a decrease in the parasympathetic activity, leading to a general decrease in HRV (Rossi et al., 2015; Monteze et al., 2015). SBP and DBP are also joined in $\mathrm{PC} 1$, as already expected, since they are measures that represent the blood pressure measurements in the arteries. When they present values higher than $120 / 80 \mathrm{mmHg}$ (SBC, 2016), they demonstrate the onset of hypertension and this is also associated with an autonomic malfunction (Mancia \& Grassi, 2014). Studies have shown that in hypertensive individuals there is a decrease in HRV, and in healthy individuals, lower HRV may precede the development of hypertension (Thayer, Yamamoto, and Brosschot, 2010). However, one of the hypotheses of the present study, that parasympathetic components of HRV would be positively correlated with PC1, was not confirmed.

The vital events and stress symptoms in 24 hours, one week, and one month were included in PC2. The vital events that occurred along one year probably caused physical and mental stress symptoms; this could explain why they were grouped in the same PC. Since theses variables were negatively charged, this PC was called component of reduced stress symptoms. Besides that, the vital events, as well as the stress symptoms, can cause changes in the autonomic 
function homeostasis with an imbalance between the sympathetic and parasympathetic systems and may thus promote low HRV (Pulopulos, Vanderhasselt, \& De Raedt, 2018). A positive association was found between PC2 and the RMSSD and NN50 variables for men. In this way, the greater the reduced stress symptoms, the greater the parasympathetic activity. This association would be expected, since stressors are commonly associated with an increase in sympathetic activity in the heart, with a decrease in parasympathetic activity, or with both effects (Kim, Cheon, Bai, Lee, \& Koo, 2018).

PC3 included the variables labor demand (with negative load) and social support at work (with positive load), and was named a component of favorable working conditions. It is suggested that, if the work environment presents good conditions, that is, if the professional has work demands that are consistent with his/her function, as well as the existence of a good relationship between co-workers, boss, and students (high social support at work), it is associated with a higher HRV. In this study, NN50 (for men) and HF (for women) were positively associated with PC3 (component of favorable working conditions), that is, the higher the favorable working conditions, the greater the parasympathetic activity. This result was expected, since good working conditions should be related to high vagal activity in resting. Some authors corroborated these findings, showing that high stress at work is associated with low HRV (Järvelin-Pasanen, Sinikallio, \& Tarvainen, 2018). Thus, when the teacher presented a healthy balance between the demand and social support at work, he had a higher HRV, which could reduce the risk of cardiovascular disease.

Finally, in PC4 (component of labor and physiological deregulation), HRrest (with positive load) and labor activity control (with negative load) were included. A positive association of this component with HF was found for both sexes. This result was contrary to our hypotheses since a lower control of labor activities and high HRrest should be a bad health condition and, consequently, should be related to low HF (parasympathetic activity). In this study, it can be suggested that the decrease in the favorable conditions at work (decreased control of labor tasks) and increase in heart rate at rest was not enough to stimulate vagal output, since the sample of this paper was composed of professors of a Public University in which the employees receive higher salaries and have work stability in comparison with High School and Private University teachers (Inep, 2004; Carmo, Fleck, \& Santos, 2015 ).

Body mass, height, BMI, CC, and WHR were higher in men than in women, while BF\% was higher in women than in men. These sex-related anthropometric differences in university professors corroborate differences already shown in another sample (Oliveira et al., 2011). Women presented lower mean values of SBP and DBP in relation to men, corroborating the findings of Silva, Oliveira \& Pierin (2016). This suggests that men have a higher risk of developing arterial hypertension and of having health-related complications, which has already been shown by the Brazilian Society Of Cardiology (2010). According to Silva, Oliveira \& Pierin (2016), the fact that women have lower blood pressure values could be because women take better care of their health and seek medical help more frequently and follow the indicated treatments correctly; therefore, sex is an important variable that deserves attention when it comes to hypertension.

Among the stress variables, the women in the present study presented higher values in the physical and psychological symptoms of stress in one week compared to men. Other studies also demonstrated sex differences for stress-related variables (Bale \& Epperson, 2015). According to Bale \& Epperson (2015) and Zibetti \& Pereira (2010), the highest values of the stress variable in the female sample appear to involve an interaction of sex genes and hormonal changes, and the role of women in society, leading to a double work shift schedule. In addition, teaching also has a double working day trait, since the time spent at the university, in general, is not enough to perform all the required activities, such as planning classes, correcting assignments and tests, doing research, etc. ( Ruza, Silva, \& Pádua, 2015). In this 
situation, female professors end up presenting more physical and psychological symptoms of stress. Different from the initial hypothesis, there was no significant difference between the sexes for the parasympathetic components of HRV. This fact contrasts to results found by Voss, Schroeder, Heitmann, Peters, \& Perz (2015), but corroborates other studies (Moodithaya \& Avadhany, 2012; Vanderlei et al., 2012). This lack of congruence in the literature can be explained by different methods of HRV component processing, unequal numbers between men and women, lack of collection of respiratory parameters, very variable age , and physical training (Quintana \& Heathers, 2015; Laborde, Mosley, \& Thayer, 2017).

There were some limitations in this study. Firstly, (i) the sample is composed by professors of a specific Brazilian countryside university; (ii) the sample was comprised mostly by men (63.1\%); (iii) other physiological measures (e.g. respiratory rate, hormonal secretions, and neurotransmitter levels) could be used; (iv) mental disorders were assessed only by a simple yes/no questionnaire; and (v) the wide age range could be a factor of influence in the results; however, no significant correlations were obtained between age and the HRV parameters (SDNN: rho $=-0.21, \mathrm{p}=0.08 ; \mathrm{HF}: \mathrm{rho}=0.10, \mathrm{p}=0.41 ; \mathrm{NN} 50: \mathrm{r}=0.23, \mathrm{p}=0.07$ ).

However, the strengths of this study were that (i) a relevant highly stressed sample that is little studied in the literature was used; (ii) several psychological and physiological parameters were measured in the same sample; and (iii) the Principal Component Analysis (PCA), a multivariate technique that is a suitable alternative for analyzing this kind of data, was used.

\section{Conclusion}

We concluded that the parasympathetic parameters of the HRV are positively associated with the components of reduced stress symptoms, favorable working conditions, and labor and physiological deregulation. These principal components, therefore, seem to be the most related to the cardiac parasympathetic activity of teachers and therefore deserve greater emphasis in future research. Since the everyday life of professors is stressful, they could try to increase their cardiac parasympathetic activity by doing, for example, exercises, yoga, or cardiovascular biofeedback, in order to counterbalance the stress effects of their routine. Future studies carried out in the sample of professors could investigate a longer length of heart rate variability (e.g. 24h), a direct stress task (e.g. Arithmetic task); and specific mental disorders (e.g. Depression, Anxiety, Burnout).

\section{References}

Alves, M. G. de M., Chor, D., Faerstein, E., Lopes, C. de S., \& Werneck, G. L. (2004). Versão resumida da "job stress scale": adaptação para o português. Revista de Saúde Pública, 38(2), 164-171. DOI:10.1590/s0034-89102004000200003

Bale, T. L., \& Epperson, C. N. (2015). Sex differences and stress across the lifespan. Nature Neuroscience, 18(10), 1413-1420. DOI:10.1038/nn.4112

Balzarotti, S., Biassoni, F., Colombo, B., \& Ciceri, M. R. (2017). Cardiac vagal control as a marker of emotion regulation in healthy adults: A review. Biological Psychology, 130, 54-66. DOI:10.1016/j.biopsycho.2017.10.008

Beauchaine, T. P., \& Thayer, J. F. (2015). Heart rate variability as a transdiagnostic biomarker of psychopathology. International Journal of Psychophysiology, 98(2), 338350. DOI:10.1016/j.ijpsycho.2015.08.004

Benichou, T., Pereira, B., Mermillod, M., Tauveron, I., Pfabigan, D., Maqdasy, S., \& Dutheil, F. (2018). Heart rate variability in type 2 diabetes mellitus: A systematic review and meta-analysis. PLOS ONE, 13(4), 119. DOI:10.1371/journal.pone.0195166

Braga, M. M., \& Paternez, A. C. A. C. (2011). Avaliação do consumo alimentar de professores de uma universidade particular da cidade de São Paulo (SP). Rev. Simbio-Logias, 4(6):84-97. https://www.ibb.unesp.br/Home/ensino/departamentos/educacao/revistasimbio- 
logias/avaliacao-do-consumo-alimentar-de-professores-de-uma-universidade-particular-dacidade-de-sao-pau.pdf

Carmo, K. L. F., Fleck, C. F., Santos, J. U. L. (2015). Docente em universidade pública ou privada? Desafios, oportunidades e diferenças. RAIMED - Revista de Administração IMED, 5(2): 166-180. DOI: 10.18256/22377956/raimed.v5n2p166-180

Chatkoff, D. K., Maier, K. J., \& Klein, C. (2010). Nonlinear associations between chronic stress and cardiovascular reactivity and recovery. International Journal of Psychophysiology, 77(2), 150-156. DOI:10.1016/j.ijpsycho.2010.05.008

Draper, N. R., \& Smith, H. (2014). Applied regression analysis. John Wiley \& Sons.

Durnin, J. V. G. A., \& Womersley, J. (1974). Body fat assessed from total body density and its estimation from skinfold thickness: measurements on 481 men and women aged from 16 to 72 Years. British Journal of Nutrition, 32(01), 7797. DOI:10.1079/bjn19740060

Ernst, G. (2017). Hidden Signals - The History and Methods of Heart Rate Variability. Front Public Health, 5: 265. DOI: 10.3389/fpubh.2017.00265

Fang, H., Berg, E., Cheng, X. \& Shen, W. How to best assess abdominal obesity. Curr. Opin. Clin. Nutr. Metab. Care 21, 360-365 (2018).

Fidalgo, N. L. R. (2010) A espetacularização do trabalho docente universitário: dilemas entre produzir e viver e viver para produzir. Tese de Doutorado, Programa de PósGraduação em Educação da Universidade Federal de Minas Gerais. 200p. Belo Horizonte.

Frenzel, A. C., Pekrun, R., Goetz, T., Daniels, L. M., Durksen, T. L., Becker-Kurz, B., \& Klassen, R. M. (2016). Measuring Teachers' enjoyment, anger, and anxiety: The Teacher Emotions Scales (TES). Contemporary Educational Psychology, 46, 148-163. doi:10.1016/j.cedpsych.2016.05.003

Guedes, D. P., \& Guedes, J. E. R. P. (1998). Controle do peso corporal: composição corporal, atividade física e nutrição. Londrina: Midiograf.

Hajare, R. (2018). The True Principal Health and Investigation of The High Burnout Stages Experienced by Professors Working in Pharmacy Institutions Pune University and Related Factors: an Important Study. Medical Research and Clinical Case Reports 1(2): 66-72.

Hayano, J., \& Yasuma, F. (2003). Hypothesis: respiratory sinus arrhythmia is an intrinsic resting function of cardiopulmonary system. Cardiovascular Research, 58 (1), 19. DOI: 10.1016 / s0008-6363 (02) 00851-9

Hu, L., Huang, X., You, C., Li, J., Hong, K., Li, P., Cheng, X. Wu, Y. Wu, Q. Wang, Z. Gao, R. Bao, H. (2017). Prevalence of overweight, obesity, abdominal obesity and obesity-related risk factors in southern China. PLOS ONE, 12 (9), e0183934. doi: 10.1371 / journal.pone.0183934

Huang, C.-J., Webb, H. E., Zourdos, M. C., \& Acevedo, E. O. (2013). Cardiovascular reactivity, stress, and physical activity. Frontiers in Physiology, 4. DOI: $10.3389 /$ fphys.2013.00314

International Diabetes Federation (IDF). (2006). The IDF consensus worldwide definition of the metabolic syndrome. http://www.idf.org/webdata/docs/MetSyndrome_ FINAL.pdf.

Instituto Nacional de Estudos e Pesquisas Educacionais Anísio Teixeira (Inep) (2004). Estatísticas dos professores no Brasil, 2. ed. - (46). Brasília. http://portal.inep.gov.br/documents/186968/484154/Estat\%C3\%ADsticas+dos+ professores + no + Brasil/2cfab3f2-3221-4494-9f7e-63ae08c154e1?version=1.1

Järvelin-Pasanen, S., Sinikallio, S., \& Tarvainen, M. P. (2018). Heart rate variability and occupational stress — systematic review. Industrial Health, 56(6): 500- 
Kanter, R., \& Caballero, B. (2012). Global gender disparities in obesity: a review. Advances in Nutrition, 3(4), 491-498. DOI:10.3945/an.112.002063

Kim, H. G., Cheon, E. J., Bai, D. S., Lee, Y. H., \& Koo, B. H. (2018). Stress and Heart Rate Variability: A Meta-Analysis and Review of the Literature. Psychiatry Investigation, 15(3), 235-245. DOI:10.30773/pi.2017.08.17

koenig, J., \& Thayer, J. F. (2016). Sex differences in healthy human heart rate variability: A meta-analysis. Neuroscience \& Biobehavioral Reviews, 64, 288310. DOI:10.1016/j.neubiorev.2016.03.007

Kop, W. J., Stein, P. K., Tracy, R. P., Barzilay, J. I., Schulz, R., \& Gottdiener, J. S. (2010). Autonomic nervous system dysfunction and inflammation contribute to the increased cardiovascular mortality risk associated with depression. Psychosomatic Medicine, 72(7), 626-635. DOI:10.1097/psy.0b013e3181eadd2b

Laborde, S., Mosley, E., \& Thayer, J. F. (2017). Heart rate variability and cardiac vagal tone in psychophysiological research - recommendations for experiment planning, data analysis, and data reporting. Frontiers Psychology, 8: 213. DOI: $10.3389 /$ fpsyg.2017.00213

Lipp, M. E. N. (2000). Manual do inventário de sintomas de stress para adultos de Lipp (LSSI). São Paulo: Casa do Psicólogo.

Mancia G, Grassi G. The autonomic nervous system and hypertension. Circ Res. 2014;114:1804-1814. doi: 10.1161/CIRCRESAHA.114.302524

Reis, B. M. \& Cecílio, S. (2014). Precarização, trabalho docente intensificado e saúde de professores universitários. Trabalho \& Educação, 23(2), 109-128.

Mardia, K. V., Kent, J. T., \& Bibby, J. M. (1979). Multivariate analysis. New York, NY: Academic Press.

Martins, A. P. B. (2018). A obesidade deve ser tratada como uma questão de saúde pública. Rev. adm. Empres, 58(3), 337-341. http://dx.doi.org/10.1590/s0034759020180312 .

Mayor, E. (2015). Gender roles and traits in stress and health. Frontiers in Psychology, 6:779. https://doi.org/10.3389/fpsyg.2015.00779

Monteze, N. M., Souza, B. B., Alves, H. J. de P., de Oliveira, F. L. P., de Oliveira, J. M., de Freitas, Neto, R. M. do N., Sales M. L., \& Souza, G. G. L. (2015). Heart Rate Variability in Shift Workers: Responses to Orthostatism and Relationships with Anthropometry, Body Composition, and Blood Pressure. BioMed Research International, 2015, 1-8. DOI:10.1155/2015/329057

Moodithaya, S., \& Avadhany, S. T. (2012). Gender Differences in Age-Related Changes in Cardiac Autonomic Nervous Function. Journal of Aging Research, 2012, 17. doi:10.1155/2012/679345

Moreira, O. C., de Oliveira, R. A. R., Neto, F. A. Amorim, W., Oliveira, C. E. P., Doimo, L. A., Amorim, P. R. dos S., Laterza, M. C., Monteiro, W. D., \& Marins, J. C. B. (2011). Associação entre risco cardiovascular e hipertensão arterial em professores universitários. Revista Brasileira de Educação Física e Esporte. 25(3):397-406, https://www.researchgate.net/publication/303249527_Associacao_entre_risco_c ardiovascular_e hipertensao arterial em professores universitarios.

Oliveira, R. A. R. Moreira, O. C., Neto, F. A., Amorim, W., Costa, E. G., \& Marins, J. C. B. (2011). Prevalence of overweight and obesity in professors of University Federal of Vicosa, 24(4):603-612. DOI: https://doi.org/10.1590/S010351502011000400003 
Porges, S. W. (2007). The polyvagal perspective. Biological Psychology, 74(2), 116-143. DOI:10.1016/j.biopsycho.2006.06.009

Pulopulos, M. M., Vanderhasselt, M.-A., \& de Raedt, R. (2018). Association between changes in heart rate variability during the anticipation of a stressful situation and the stress-induced cortisol response. Psychoneuroendocrinology, 94, 6371. DOI:10.1016/j.psyneuen.2018.05.004

Quintana, D. S., \& Heathers, J. A. J. (2014). Considerations in the assessment of heart rate variability in biobehavioral research. Frontiers in Psychology, 5. doi:10.3389/fpsyg.2014.00805

R Core Team (2017). $R$ : A language and environment for statistical computing. https://www.R-project.org

Reckelhoff, J. F. (2018). Gender differences in hypertension. Current Opinion in Nephrology and Hypertension, 1. DOI:10.1097/mnh.0000000000000404

Rossi, R. C., Vanderlei, L. C. M., Gonçalves, A. C. C. R., Vanderlei, F. M., Bernardo, A. F. B., Yamada, K. M. H., da Silva, N. T., \& de Abreu, L. C. (2015). Impact of obesity on autonomic modulation, heart rate and blood pressure in obese young people. Autonomic Neuroscience, 193, 138-141. DOI:10.1016/j.autneu.2015.07.424

Ruza, F. M., Silva, S. A. \& Pádua, K. C. (2015). Ser professor universitário: identidades construídas entre aspectos de satisfação e insatisfação profissional. Linhas Críticas, 21(44), 179-198. https://periodicos.unb.br/index.php/linhascriticas/article/view/4514Sammito, S., Sammito, W., \& Böckelmann, I. (2016). The circadian rhythm of heart rate variability. Biological Rhythm Research, 47(5), 717730. DOI:10.1080/09291016.2016.1183887

Sanchez, H. M., Sanches, G. M., Barbosa, M. A., Guimarães, E. C., \& Porto, C. C. (2019). Impact of health on quality of life and quality of working life of university teachers from different areas of knowledge. Ciênc. saúde coletiva, 24(11), 4111-4123. http://dx.doi.org/10.1590/1413-812320182411.28712017.

Santos, V. M., Pinto, D. S., Santana, G. M. S., Brito, L. G. A., \& Pithon, K. R. (2018). Chronic non-communicable diseases: cardiovascular risk factors in university professors. O Mundo da Saúde, 42(3):551-568. DOI: 10.15343/01047809.20184203551568

Savoia, M. G. (1999). Escalas de eventos vitais e estratégias de enfrentamento (coping). Revista de Psiquiatria Clínica, 26(2):57-67. https://scholar.google.com/scholar_lookup?title=Escalas+de+eventos+vitais+e+ de + estrat $\%$ C3\%A9gias + de + enfrentamento + (coping)\&author=Savoia + M. + G.\&p ublication_year $=1999 \&$ journal $=$ Revista + de + Psiquiatria $+\mathrm{Cl} \% \mathrm{C} 3 \% \mathrm{ADnica} \&$ volu $\mathrm{me}=26 \&$ pages $=57-67$

Schutz, P. A. (2014). Inquiry on Teachers' Emotion. Educational Psychologist, 49(1), 112. DOI: $10.1080 / 00461520.2013 .864955$

Silva, S. S. B. E., Oliveira, S. F. S. B., \& Pierin, A. M. G. (2016). O controle da hipertensão arterial em mulheres e homens: uma análise comparativa. Revista da Escola de Enfermagem da USP, 50(1): 50-58. DOI: http://dx.doi.org/10.1590/S0080623420160000100007

Silveira, K. A., Enumo, S. R. F., Paula, K. M. P. de, \& Batista, E. P. (2014). Estresse e enfrentamento em professores: uma análise da literatura. Educação Em Revista, 30(4), 15-36. DOI:10.1590/s0102-46982014000400002

Sociedade Brasileira De Cardiologia (SBC), Sociedade Brasileira de Hipertensão, and Sociedade Brasileira de Nefrologia. (2010). "VI Brazilian guidelines on hypertension”. Arquivos Brasileiros de Cardiologia, 95(1 Suppl):1-51. Erratum 
in: Arq Bras Cardiol. 2010;95(4):553. PMID: 21085756

Sociedade Brasileira de Cardiologia (SBC). (2016). "VII Brazilian guidelines on hypertension" Arquivos Brasileiros de Cardiologia, 107(3 suppl):1-83. https://doi.org/10.5935/abc.20160140

Task Force. (1996). Heart rate variability: standards of measurement, physiological interpretation and clinical use. Task Force of the European Society of Cardiology and the North American Society of Pacing and Electrophysiology, Circulation, 93(5): 1043-1065.

Thayer, J. F., Hansen, A. L., Saus-Rose, E., \& Johnsen, B. H. (2009). Heart rate variability, prefrontal neural function, and cognitive performance: the neurovisceral integration perspective on self-regulation, adaptation, and health. Annals of Behavioral Medicine, 37, 141-153. DOI:10.1007/s12160-009-9101-z

Thayer, J. F., Yamamoto, S. S., \& Brosschot, J. F. (2010). The relationship of autonomic imbalance, heart rate variability and cardiovascular disease risk factors. International Journal of Cardiology, 141(2), 122131. doi:10.1016/j.ijcard.2009.09.543

Theorell, T., \& Karasek, R. A. (1996). Current issues relating to psychosocial job strain and cardiovascular disease research. Journal of Occupational Health Psychology, 1(1), 9-26. DOI:10.1037/1076-8998.1.1.9.

Vanderlei, F. M., Rossi, R. C., de Souza, N. M., de Sá, D. A, Gonçalves, T. M., Pastre, C. M., de Abreu, L. C., Valenti, V. E., \& L. C. M Vanderlei. (2012). Heart rate variability in healthy adolescents at rest. Journal of Human Growth and Development; $22(2)$ : https://www.researchgate.net/publication/317462260

173-178.

Verma, R., Balhara, Y. P. S. \& Gupta, C. S. (2011). Gender differences in stress response: Role of developmental and biological determinants. Ind Psychiatry J., 20(1): 4 10, DOI: 10.4103 / 0972-6748.98407

Voss, A., Schroeder, R., Heitmann, A., Peters, A., \& Perz, S. (2015). Short-Term Heart Rate Variability-Influence of Gender and Age in Healthy Subjects. PLOS ONE, 10(3), 1-33. DOI:10.1371/journal.pone.0118308

World Health Organization (WHO). (2000). Obesity: preventing and managing the global epidemic. Report of a WHO consultation. World Health Organ Tech Rep Ser., 894(1-12):1-253.

https://www.who.int/nutrition/publications/obesity/WHO_TRS_894/en/

Yadav, R. L., Yadav, P. K., Yadav, L. K., Agrawal, K., Sah, S. K., \& Islam, M. N. (2017). Association between obesity and heart rate variability indices: an intuition toward cardiac autonomic alteration - a risk of CVD. Diabetes, Metabolic Syndrome and Obesity: Targets and Therapy, 10, 5764. DOI:10.2147/dmso.s 123935

Yue, W., Yin, J., Chen, B., Zhang, X., Wang, G., Li, Chen, H. \& Jia, R. (2014). Analysis of Heart Rate Variability in Masked Hypertension. Cell Biochemistry and Biophysics, 70(1), 201-204. DOI:10.1007/s12013-014-9882-y

Xhyheri, B., Manfrini, O., Mazzolini, M., Pizzi, C., \& Bugiardini, R. (2012). Heart Rate Variability Today. Progress in Cardiovascular Diseases, 55(3), 321331. DOI:10.1016/j.pcad.2012.09.001

Zibetti, M. L. T. \& Pereira, S. R. (2010) Mulheres e professoras: repercussões da dupla jornada nas condições de vida e no trabalho docente . Educar em Revista, Curitiba, Brasil, n. especial 2, p. 259-276. Editora UFPR https://doi.org/10.1590/S0104-40602010000500016 